\title{
PRANGOS PLATYCHLAENA BOISS ESSENTIAL OILS: A NOVEL STUDY ON ITS TOXICITY, ANTIBACTERIAL ACTIVITY AND CHEMICAL COMPOSITIONS EFFECT ON BURN RATS
}

\begin{abstract}
J. K. Rahman
Lecturer

College of Science

Salahaddin Uni.

jwanbio9@gmail.com

ABSTRACT

The Prangos platychlaena Boiss belonged to the family of Apiaceae is a native medicinal plant of Kurdistan-Iraq. The stem, leaves and flowers of the plant were collected in the mountain of Halgurd of the Kurdistan region of Iraq, and hydrodistilated to obtain the volatile compounds, using both Gas Chromatography ( GC ) and Gas chromatography/ Mass spectroscopy (GC/MS). The results showed that the P. platychlaena Boiss essential oils containing several compounds such as Sylvestrene, $\alpha$-Pinene oxide, (Z)-Epoxy-ocimene, Borneol, epiLongipinanol, Germacrene D-4-ol, epi- $\alpha$-Cadinol, 3-Thujanol acetate and Acorenone with different amount which were not found in any other Prangos species, and all showed antibacterial activity. This experiment was concducted to reveal the toxicity of flowers essentail oils of the P.platychlaena Boiss on skin burns of the rat. The results revealed that the base cream which contains $1 \%$ of the essentail oils showd less time in healing wounds in comparing with the other groups. Histological examination of the treated ones showed significantly the formation of new epiderm in those rats which were receiving the base cream containg $1 \%$ essentail oils. These finding sugested that the essentail oils of this plant can be used as a surface treatment agent for the human burns.

D. Dastan

School of Pharmacy

Hamadan Uni.

dara962@gmail.com
\end{abstract}

Key word: skin,chromatography, wound, pinene

رحمن وآخرون

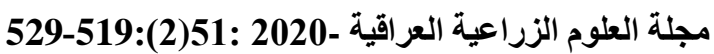

الزيوت الأساسية لبرنقوس المسطح (PRANGOS PLATYCHLAENA BOISS ): دراسة عن تاثير سميته ،

$$
\text { ومضادات الجراثيم والموكناتها الكيميائيةعلى حرق الفئران }
$$

\begin{tabular}{|c|c|}
\hline دارا داستان & دارا محمد امين جاف \\
\hline استاذ مساعد & استاذ مساعد \\
\hline كلية الصيدلية & كلية التربية \\
\hline الجامعة صلاحدين & لحدين \\
\hline
\end{tabular}




\section{INTRODUCTION}

Mountain region of the north of Iraq, is well known for the diversity of the wild plants and their natural products used as fodder, for a long time by its habitants, traditional medicine and other purposes(3). The family of Apiaceae is regarded as one of the important famililes, with its different species. The genus of Prangos belongs to the family of Apiaceae, under the order of apiales, having 30 species, distributed from the Mediterranean to central Asia, 14 of them were found in Turkey (2), while seven of them distributed in the Kurdistan region of Iraq which are P.platychlaena Boiss., P.ferulacea (L.), P. uloptera DC., P.asperula Boiss., P.pabularia Lindl., P.peucedanifolia Fenz, and P.carymbosa Boiss . P. platychlaena Boiss is a perennial plant, length can reach up to (1$1.5 \mathrm{~m})$, This plant is found naturally growing in the mountain of Kurdistan region, it contains different quantities of the essential oils and other phytochemical compounds, which plays an important role in the antibacterial activity and in the wound healing process (11) . Toxicity assay is regarded as an important aspect among the process of wound healing. This process promoted by plant products, which possessed the effect with no or less toxicity compared with the synthetic drugs. A part of this study is concerning the essential oil compounds from the leaves, stems and flowers of $P$. platychlaena Boiss which deals with the chemical compositions, antibacterial activity and the toxicity of essential oils of the $P$. platychlaena Boiss. Up to date of reported literatures concerning this function of the $P$. platychlaena Bioss, covering the investigations about this plant species, were not found.

\section{MATERIALS AND METHODS}

\section{Collection of plant materials}

The Prangos platychlaena Boiss leaves, stem and flowers were collected during May -July 2017 from the Halgurd mountain in Kurdistan region of Iraq, at the altitude of $2170 \mathrm{~m}$. above sea level, latitude $36: 42.30758 \mathrm{~N}$ and longitude 44:52.29358E which then were identified by the professional taxonomist from the department of biology, College of Education ,Salahaddin university-Erbil.

Essential oil isolation: The oils of the P.platychlaena plant parts were extracted by the hydrodistillation process for 4 hours, using a Clevenger-type apparatus then was dried by using $\mathrm{Na}_{2} \mathrm{SO}_{4}$. The obtained essential oil was kept in a darkly closed vial at $4^{\circ} \mathrm{C}$ (4).

\section{Density of essential oil}

The density of essential oils was determined as the weight of essential oil extract (g) per volume of essential oils.

\section{The yield of essential oils}

The oils yield of leaves, stem and flowers were determined as percent volume $(\mathrm{ml})$ of essential oil per fresh weight $(\mathrm{g})$ of the plant part $(\% \mathrm{v} / \mathrm{m})$.

\section{GC and GC/MS analysis}

The oils from leaves, stem and flowers samples were analysis by using GasChromatography (GC), with a flameionization detector (FID). The processes were carried out by using fused silica capillary DB5 column $(60 \mathrm{~m} \times 0.5 \mathrm{~mm}$, film thicken 0.5 $\mu \mathrm{m})$.The temperatures of the detector and injector were $300.0^{\circ} \quad \mathrm{C}$ and $250.0^{\circ} \mathrm{C}$ respectively. The $\mathrm{N}_{2}$ as the carrier gas at a flow rate of $1 \mathrm{ml} / \mathrm{min}$, oven temperature was from $60^{\circ} \mathrm{C}$ to $250^{\circ} \mathrm{C}$ at the rate of $5^{\circ} \mathrm{C} / \mathrm{min}$ was programmed, and finally held isothermally for 10mins. Analysis of oil by Gas Chromatography/Mas Spectroscopy (GC/MS) was performed by using a thermoquestFinnigan gas chromatograph with the column mentioned above, with the same conditions coupled to a TRACE mass spectrometer. The scanning of mass ranged from 43 to $456 \mathrm{~m} / \mathrm{z}$. The voltage of ionization was $70 \mathrm{eV}$. The tempretures for the ion source and the interface were kept at $200^{\circ} \mathrm{C}$ and $250^{\circ} \mathrm{C}$, respectively(9).

\section{Identification of compounds}

The identification of oil constituents in leaves, stem and flowers of the P.platychlaena plants were performed by calculating of their retention indices under the same chromatographic conditions for the n-alkanes $\left(\mathrm{C}_{6}-\mathrm{C}_{24}\right)$ and oil on a DB-5 column. Identification of the oils were performed by comparing their mass spectra with those of the library standards or the authentic compounds, while for confirming compounds, the percentage of their relative areas were obtained by Flame Ionization Detector (FID), which used without using of correction factors(9). 


\section{Bacterial strain}

The in vitro antimicrobial activities of the essential oils compounds were carried out, by using pathogenic bacteria such as Staphylococcus aureus ATCC 6538P, clinical Staphylococcus aureus, Pseudomonas aeruginosa ATCC 9027, clinical Pseudomonas aeruginosa. The pathogen bacteria was isolated from human, which obtained from the Media Diagnostic Health Center in Erbil city.

\section{Culture media and activation of bacterial strain}

The medium of Mueller-Hinton broth was used for cultivation of bacteria. The inocula were prepared by transferring several single colonies of microbes into a sterile broth media and mixed together, then incubated at $37^{\circ} \mathrm{C}$ for overnight. Inoculum of the culture solution was adjusted to the McFarland scale 0.5 and confirmed by spectrophotometrical reading at $580 \mathrm{~nm}(12,16)$.

\section{Evaluation of antibacterial activities}

Bacterial activities of the essential oils were assessed by the Microdilution method according to previous methods $(8,9)$, this used for determining of the minimum Inhibitory Concentration (MIC) of the $P$. platychlaena Boiss. The assay was carried out in 96-well sterile micro plates, then, $100 \mu 1$ of nutrient broth was added to each well of the microplate. The first well was filled with $100 \mu 1$ of the essential oils. Next, by transferring $100 \mu \mathrm{l}$ content from the first well into the next well of the same row of the microplate, after mixing the content of the well, this procedure was repeated for the following well of the same row to obtain serial dilution of 1:2, 1:4, 1:8, 1:16, etc., in this case, the concentration of the sample will decrease, while the pure dimethyl sulfoxide and broth media were used as negative control, whearas Ciprofloxacin (antibacteria) were considered as references. For each well, a microbial suspension of working solution was inoculated. The absorbance for each well was measured at $630 \mathrm{~nm}$ before incubation time; by using ELISA Microplate Reader, the microplate was incubated at $37{ }^{\circ} \mathrm{C}$ for $24 \mathrm{~h}$ for the growth of bacteria. The absorbance was re-measured after incubation time to compare with the initial measurement. The MIC was calculated at the break point concentrations by comparing the absorbance before and after incubation time.

\section{Preparation of cream}

Different percentages of the flower essential oils of $P$. platychlaena Boiss were mixed with base cream (Cream contains: Micro Crstalline Wax, Hard Paraffin Wax, Light liquid Paraffin; Made in India; N.C.No.:MH/COS/KD-C-323), which obtained from local Pharmaceutical, was homogenized for $15 \mathrm{~min}$ at $25^{\circ} \mathrm{C}$, the mixture stored at $4^{\circ} \mathrm{C}$ during the experiments (21).

\section{Animals}

The experiment was conducted at the Biology department, College of education, University of Salahaddin, using adult female albino rat (Rattu norvegicus), weighting (180-200) g, age (8-10) weeks. They were housed under standard conditions (12h.light, 12h.dark) photoperiod, at temperature $23-25^{\circ} \mathrm{C}$, humidity $60 \pm 5 \%$, having standard diets and free access to tap water. All animals were housed in plastic cages $(38 \times 18 \times 30) \mathrm{cm}$, bedded with the chip of wooden which sterilized with UV light about $1.5 \mathrm{hr}$. During the experiment, 2 animals were kept in each cage to avoid removing of cream on the surface of burn. Each animal received treatment once per day during the light phase $(9.00 \mathrm{am})(1)$.

\section{Burn wound model}

The rat was anaesthetized by intramuscular injection of Ketamine $(85 \mathrm{mg} / \mathrm{Kg}$ of body weight), and Xylazine (6 $\mathrm{mg} / \mathrm{Kg}$ of body weight); (Interchemic, Holland ) (11). The sterilized clipper was used to shave the back of rats, the plate circular weighting $50.0 \mathrm{~g}$., 2.0 $\mathrm{cm}$ diameter, was heated with the flame of Bunsen burner until the temperature reached to $120^{\circ} \mathrm{C}$, measured with an infrared thermometer. The plate was induced for 10 seconds on the back of rats under controlled condition. This method allowed the seconddegree burn injury of skin (7).

\section{Experimental design}

Group 1: without burn using for anatomical analysis

Group 2: Burned skin rat treated with base cream only (lacking any effective agent).

Group 3: burned skin rat receive MEBO ointment (MEBO contain $0.25 \% \quad \mathrm{w} / \mathrm{w} \quad \beta$ - 
sitosterol; Gulf Pharmaceutical industries, Ras Al Khaimah, U.A.E).

Group 4, 5, 6, 7 and 8: Burned skin rats were treated with a cream containing $(0.5 \%, 1 \%$, $2 \%, 4 \%$ and $8 \%$ ) of flowers essential oils, respectively.

\section{Anatomical study}

After 14 days, the sample of the treated rats skin area were collected and fixed in $10 \%$ formal saline for $(24-48) \mathrm{h}$, then dehydrated in a concentration gradient including absolute ethanol, the clearing process was performed by using xylol solution, followed by paraffin wax for infiltrate and embedded process. The paraffin sections cut into $4 \mu \mathrm{m}$ - thick section, then stained by Gill haematoxylin and eosin, all slide were photographed and examined with the digital camera that connected to the light microscope(19).

\section{Statistical analysis}

The antimicrobial activity and toxicity of $P$. platychlaena Boiss were statisticaly analyzed using Kruskal- Wallis test and Dunn's multiple comparision test by Graph Pad-Prism version 7. All results arranged as mean \pm SE for each Properties and $P$ value less than 0.05 considered as statistically significant differences among them.

\section{RESULTS AND DISCUSSION}

The chemical composition of essential oils of P. platychlaena Boiss

The essential oils of P.platychlaena Boiss. was isolated by the hydrodistillation process, the yields (v/w)\% of the leaves, stem and flowers based on the fresh weight represented $0.27 \%$, $0.04 \%$ and $1.02 \%$, respectively. While, the density of each of leaves, stem and flowers were $0.97,0.94$ and 0.95 , respectively (Table 1). Identified (36, 38 and 43) compounds in leaves, stems and flowers, respectively, which accounted for $90.44 \%, 92.72 \%$ and 96.49 of the essential oil content in the three parts of $P$. platychlaena Boiss., respectively. The qualitative and quantitative values of each essential oil compounds with the retention time indices of the identified compounds were tabulated in Table 2. The major compounds of the essential oil (E)- $\beta$-Ocimene $(25.93 \%)$, Bornyl acetate $(24.58 \%)$ and $\alpha$-Pinene $(5.84 \%)$, sylvestrene $(4.62 \%), \quad \gamma$-Terpinene $(3.75 \%), \quad \delta$-Cadinene $(2.74 \%)$, Myrcene $(2.61 \%)$ and p-Cymene (2.55\%) were in leaves extraction, whereas the stems main compounds were Bornyl acetate $(25.49 \%)$, (E)- $\beta$-Ocimene (22.94\%), $\alpha$-Pinene (9.5\%), p-Cymene (6.48), $\gamma$-Terpinene $(4.13 \%)$, Sylvestrene $(4.01 \%)$, Myrcene (2.97\%) and $\delta$-3-Carene $(2.76 \%)$, and major compounds of the flower essential oils which were (E)- $\beta$-Ocimene (28.5\%), Bornyl acetate $(24.18 \%), \quad \gamma$-Terpinene (14.15\%), p-Cymene (6.48\%), $\alpha$-Pinene $(4.16 \%)$, Sylvestrene $(3.02 \%)$ and Terpinolene $(2.41 \%)$. The leaves essential oil of $P$. platychlaena Boiss. containes 14 hydrocarbon monoterpenes which represents (49.5\%), 7 oxygenated monoterpene $(27.09 \%), 9$ hydrocarbon sesquiterpene represents $(6.01 \%)$, and 6 oxygenated sesquiterpene represents $(7.87 \%)$, while their stem essential oils contains 14 hydrocarbon monoterpene represents $(57.35 \%), \quad 8$ oxygenated monoterpenes $(28.48 \%), 9$ hydrocarbon sesquiterpene $(1.89 \%)$ and 7 oxygenated sesquiterpenes $(5 \%)$. As well as the flowers of P. platychlaena Boiss contains 13 hydrocarbon monoterpenes which represent $(64.54 \%), \quad 10$ oxygenated monoterpenes (27.11\%), 9 hydrocarbon sesquiterpene represents $(3.17 \%), \quad 7$ oxygenated sesquiterpene $(1.31 \%), 3$ hydrocarbons $(0.29 \%)$ and other which represents $(0.07 \%)$ (Table 3).

\section{The new chemical components}

The results showed that the essential oils of the different part of $P$. platychlaena Boiss contains various chemical compounds such as Sylvestrene, $\alpha$-Pinene oxide, (Z)-Epoxyocimene, Borneol, epi-Longipinanol, Germacrene D-4-ol, epi- $\alpha$-Cadinol, 3-Thujanol acetate and Acorenone were not found in any Prangos species.

\section{Determination of antibacterial activities}

The highest antibacterial activities of essential oil toward the bacteria strains of the $S$. aureus ATCC $6538 \mathrm{P}$ was present in flowers, with the MIC values $0.86 \mathrm{mg} / \mathrm{ml}$, while the MIC value $1.16 \mathrm{mg} / \mathrm{ml}$ was recorded in leaves against $P$. aeruginosa ATCC 9027, as well as, the MIC value against $P$. aeruginosa was $5 \mathrm{mg} / \mathrm{ml}$ that present in leaves.while the stem essential oils showed hight values MIC against pathogen bacteria. Whereas, the MIC values of Ciprofloxacin for both strains of $S$. aureus were 1.0 and 1.66, respectively, also for both 
strains of $P$. aeruginosa were 1.0 and $2.33 \mathrm{mg} / \mathrm{ml}$, respectively. The statistical analysis showed that the essential oils of different part $P$. platychlaena Boiss. have significant differences $(p<0.05)$ among them against pathogen bacteria. Also, when the data compared to Ciprofloxacin it shows close or better than antimicrobial references, as show in Table 4.

\section{Toxicity of flower essential oils on burning}

This study evaluated the time of healing of rat's wound using different concentration of a new herbal ointment compared with the references ointments. The results were indicated significant differences in the healing time $(\mathrm{P}<0.05)$ among the flower essential oils, base cream (negative control) and references ointment (positive control). This results showed the better healing and shorter time for the base cream containing $1 \%$ flower essential oil with 14 days and then base cream containing $8 \%$ essential oil with 20 days, respectively, whereas the healing time of negative control and positive control were 27 days and 29 days, respectively. Increasing the concentration of flower essential oils caused to decrease the healing effects. At lower concentrations, no effect on the healing of the wound is shown, while in higher concentrations a positive effect on the close of the wound and the time of healing decreases, Figure 1.

\section{Anatomical evaluation}

The histological study indicated that the rats treated with the flowers essential oils of $P$. platychlaena Boiss after 14 to 20 days, showed considerable recovery of the skin and epidermis of treated rats, which covers the area of the burn wound complete re-structured and similar to the normal skin of the untreated rats, as shown in Figure 2.

This is the first study on the chemical compositions, antibacterial activities and an in vivo toxicity performed for the flowers essential oils of the $P$. platychlaena Boiss in Iraqi-Kurdistan region. These results indicated that the flowers of $P$. platychlaena Boiss containing more essential oils than the leaves and stem, this may possibly related to for the development stage of the plant and genetic factor(8). These results showed that the $P$. platychlaena Boiss essential oils containing a large amount of (E)- $\beta$-Ocimene, Bornyl acetate, $\gamma$-Terpinene, p-Cymene, $\alpha$-Pinene, Sylvestrene, $\delta$-Cadinene, Myrcene and Terpinolene, have important roles in the biological activity(20). According to our results some chemical compounds such as Sylvestrene, $\alpha$-Pinene oxide, (Z)-Epoxyocimene, Borneol, epi-Longipinanol, Germacrene D-4-ol, epi- $\alpha$-Cadinol, 3-Thujanol acetate and Acorenone were not found in any Prangos species. All of these data revealed, that the flowers of $P$. platychlaena Boiss were containing a larger amount of monoterpenes than both of the stems and leaves parts, whereas, the leaves containing the largest amounts of the sesquiterpene than both stem and flowers parts. In Comparison of our study with the previous studies performed on the essential oils from other Prangos species, the variations showed in the qualities and quantities of essential oils composition. The (E)- $\beta$-Ocimene, $\alpha$-Pinene, Myrcene, $p$-Cymene and $\delta$-Cadinene compounds were found in the aerial part of $P$. latiloba Korov according to (5) while Bornyl acetate, $\delta$-3-Carene, $\gamma$ Terpinene and Sylvestrene were not founded. The oil chemical composition of $\alpha$-Pinene $(0.2 \%)$, Myrcene( $0.1 \%)$ were found in the aerial part of P.heyniae, while Bornyl acetate, p-Cymene, $\quad \gamma$-Terpinene, $\delta$-3-Carene, $\delta$ Cadinene, (E)- $\beta$-Ocimene and Sylvestrene were not founded in this plant(21). Based on the available literature, this is the first study performed on the antibacterial activities for the essential oils of $P$. platychlaena Boiss. The leaves and flowers essential oils have antibacterial activites due to the presences of major compounds which were identified in our study, in the leaves and flowers such as oil (E)- $\beta$-Ocimene, Bornyl acetate, $\alpha$-Pinene, sylvestrene, $\quad \gamma$-Terpinene $\quad \delta$-Cadinene, Myrcene and p-Cymene, they were causing to inhibite the growth of bacteria. Up to now, no study on the healing time of wound recovery is available until the preparation of this manuscript. The disruption in normal skin may causes infection and alter homeostasis, the infection of a wound was and still regarded as one of the common diseases in our country(18). The healing of the wound is a complex process in dermal regeneration and the epidermal tissues, because some biological 
mechanisms such as inflammation, antimicrobial and wound contraction were involved in this process (14). According to our results, the cream which contains $1 \%$ and $8 \%$ of the essential oil showed less time in healing for wounds in compare with the other groups, as the flowers essential oils contain the major active phytochemical compounds such as (E)$\beta$-Ocimene, Bornyl acetate, $\gamma$-Terpinene, $p$ Cymene, $\quad \alpha$-Pinene, Sylvestrene and Terpinolene, Table1. Previous studies reported the results of antimicrobial and antiinflammation properties related to the acceleration of the wound healing process in rats(7), also results of this work were showed the essential oils of leaves and flowers of this plant species have antibacterial activities. As well as, most of these chemical constituents of the essential oils have properties of antimicrobial activities such as (E)- $\beta$-Ocimene ,Bornyl acetate (15) and $\alpha$-Pinene(22) or antiinflammation factors such as p-Cymene (17) and myrcene(13). Our results revealed the essential oil of flowers containing a large amount of monoterpenes may be led to decrease the time of wound healing(8). Also, our results demonstrated that by decreasing the concentration to $0.5 \%$, the time of healing increases probably for the fact that the cream at that level contains less amount of the constituents of active compounds, while by increasing oil concentration to $2 \%$ and $4 \%$, the time of wound healing are delayed because the chemical constituent of the flowers essential oils become toxic to the burned skin of rats at this concentration. As well as, by increasing the concentration of the flowers essential oil to $8 \%$, the time of healing will decrease to 20 days. This might be due to the synergists properties of the essential oils constituents. No toxicity was observable on the burned skin of rats at the maximum dosage(24). The results obtained from the histological study, concludes that flowers essential oils ointment of $P$. platychlaena Boiss. have the ability to reduce the healing time and accelerate the formation of skin tissues in treated animals which could be useful to patients suffering from burn skin.

Table 1. Yield (v/w) \% and density of essential oil in a different part of P. platychlaena Boiss

\begin{tabular}{|c|c|c|}
\hline Part of plant & Yield \% & density \\
\hline Leaves & 0.27 & 0.97 \\
Stem & 0.04 & 0.94 \\
Flower & 1.02 & 0.95 \\
\hline
\end{tabular}


Table 2. Chemical composition of essential oil of different part of P. platychlaena Boi

\begin{tabular}{|c|c|c|c|c|c|c|c|}
\hline \multirow[t]{2}{*}{ Compounds } & \multirow[b]{2}{*}{ KI } & \multicolumn{2}{|c|}{ Flower } & \multicolumn{2}{|c|}{ leaf } & \multicolumn{2}{|c|}{ stem } \\
\hline & & RT & $\%$ Area & RT & \%Area & RT & \%Area \\
\hline$\alpha$-Thujene & 924 & 3.97 & 0.18 & 3.97 & 0.08 & 3.97 & 0.14 \\
\hline$\alpha$-Pinene & 932 & 4.11 & 4.16 & 4.11 & 5.84 & 4.13 & 9.5 \\
\hline Camphene & 946 & 4.35 & 0.58 & 4.36 & 0.82 & 4.36 & 1.08 \\
\hline Verbenene & 961 & - & - & 4.45 & 0.11 & 4.44 & 0.3 \\
\hline Sabinene & 969 & 4.77 & 0.7 & 4.77 & 0.6 & 4.77 & 0.6 \\
\hline$\beta$-Pinene & 974 & 4.85 & 0.37 & 4.85 & 0.74 & 4.85 & 1.41 \\
\hline Myrcene & 988 & 5.06 & 2.05 & 5.07 & 2.61 & 5.07 & 2.97 \\
\hline$\alpha$-Phellandrene & 1002 & 5.37 & 1.8 & 5.37 & 0.32 & 5.37 & 0.23 \\
\hline$\delta$-3-Carene & 1008 & 5.48 & 0.14 & 5.48 & 0.73 & 5.49 & 2.76 \\
\hline p-Cymene & 1020 & 5.81 & 6.48 & 5.79 & 2.55 & 5.81 & 6.48 \\
\hline Sylvestrene & 1025 & 5.9 & 3.02 & 5.88 & 4.62 & 5.89 & 4.01 \\
\hline 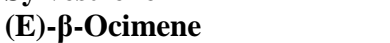 & 1044 & 6.17 & 28.5 & 6.11 & 25.93 & 6.14 & 22.94 \\
\hline$\gamma$-Terpinene & 1054 & 6.62 & 14.15 & 6.54 & 3.75 & 6.55 & 4.13 \\
\hline Terpinolene & 1088 & 6.93 & 2.41 & 6.92 & 0.8 & 6.92 & 0.8 \\
\hline$\alpha$-Pinene oxide & 1099 & 7.23 & 0.2 & 7.2 & 0.08 & 7.2 & 0.21 \\
\hline (Z)-Epoxy-ocimene & 1128 & 8.17 & 0.6 & 8.15 & 0.42 & 8.15 & 0.41 \\
\hline neo-allo-Ocimene & 1140 & 8.23 & 0.2 & 8.23 & 0.1 & 8.22 & 0.32 \\
\hline trans-Verbenol & 1140 & 8.64 & 0.94 & 8.63 & 0.35 & 8.62 & 0.6 \\
\hline Borneol & 1165 & 9.17 & 0.4 & 9.15 & 0.18 & 9.16 & 0.09 \\
\hline Terpinen-4-ol & 1174 & 9.44 & 0.05 & - & - & - & - \\
\hline p-Cymen-8-ol & 1179 & 9.71 & 0.26 & - & - & - & - \\
\hline trans-Chrysanthenyl acetate & 1235 & 11.79 & 0.18 & 11.76 & 1.35 & 11.77 & 1.27 \\
\hline Bornyl acetate & 1284 & 12.3 & 24.18 & 12.24 & 24.58 & 12.29 & 25.49 \\
\hline 3-Thujanol acetate & 1295 & 12.84 & 0.1 & - & - & 12.82 & 0.09 \\
\hline$\alpha$-Copaene & 1374 & 14.47 & 0.1 & 14.68 & 0.13 & 14.45 & 0.1 \\
\hline$\beta$-Bourbonene & 1387 & 14.7 & 0.07 & 14.84 & 0.42 & 14.85 & 0.09 \\
\hline$\beta$-Elemene & 1389 & 14.87 & 0.07 & 14.92 & 0.08 & 14.92 & 0.11 \\
\hline (E)-Caryophyllene & 1417 & 15.57 & 0.11 & 15.55 & 0.48 & 15.55 & 0.12 \\
\hline Germacrene D & 1484 & 17.1 & 2.14 & 17.06 & 1.07 & 17.06 & 0.05 \\
\hline$\beta$-Selinene & 1489 & 17.43 & 0.27 & 17.19 & 0.11 & 17.19 & 0.11 \\
\hline$\delta$-Amorphene & 1511 & 17.56 & 0.07 & 17.51 & 0.72 & 17.52 & 0.29 \\
\hline$\beta$-Curcumene & 1514 & 17.7 & 0.11 & 17.67 & 0.26 & 17.67 & 0.09 \\
\hline$\delta$-Cadinene & 1522 & - & - & 18.07 & 2.74 & 18.06 & 0.93 \\
\hline Germacrene B & 1559 & 18.08 & 0.23 & - & - & - & - \\
\hline epi-Longipinanol & 1562 & 18.89 & 0.13 & 18.88 & 0.34 & 18.81 & 0.07 \\
\hline Germacrene D-4-ol & 1574 & 19.35 & 0.05 & 19.25 & 0.16 & 19.24 & 0.07 \\
\hline Spathulenol & 1577 & 19.42 & 0.46 & 19.41 & 1.35 & 19.42 & 0.68 \\
\hline epi- $\alpha$-Cadinol & 1638 & - & - & 20.83 & 2.51 & 20.86 & 1.07 \\
\hline a-Muurolol & 1644 & 20.87 & 0.18 & - & - & 20.95 & 0.14 \\
\hline$\alpha$-Cadinol & 1644 & 21.16 & 0.36 & 21.15 & 2.09 & 21.15 & 1.51 \\
\hline Valeranone & 1674 & - & - & 21.53 & 1.42 & 21.54 & 1.46 \\
\hline Acorenone & 1692 & 21.65 & 0.07 & - & - & - & - \\
\hline Oplopanone & 1739 & 23.01 & 0.06 & - & - & 17.67 & - \\
\hline Isopropyl hexadecanoat & 2024 & 28.58 & 0.07 & - & - & - & - \\
\hline n-Tricosane & 2300 & 33.42 & 0.09 & - & - & - & - \\
\hline n-Pentacosane & 2500 & 35.07 & 0.06 & - & - & - & - \\
\hline n-Heptacosane & 2700 & 36.65 & 0.14 & - & - & - & - \\
\hline Total & & & 96.49 & & 90.44 & & 92.72 \\
\hline
\end{tabular}

RT: retention time, KI: Kovats Index, symbol -: not detected

Table 3. Chemical classes of the essential oil compounds of $P$. platychlaena Boiss. in a different parts

\begin{tabular}{|c|c|c|c|c|c|c|}
\hline \multirow[t]{2}{*}{ class chemical } & \multicolumn{2}{|c|}{ Leaf } & \multicolumn{2}{|c|}{ Stem } & \multicolumn{2}{|c|}{ Flower } \\
\hline & number & $\%$ area & numbe & \%area & number & \%area \\
\hline Monoterpene hydrocarbon & 14 & 49.5 & 14 & 57.35 & 13 & 64.54 \\
\hline Oxygenated Monoterpene & 7 & 27.06 & 8 & 28.48 & 10 & 27.11 \\
\hline Sesquiterpene hydrocarbon & 9 & 6.01 & 9 & 1.89 & 9 & 3.1 \\
\hline Oxygenated Sesquiterpene & 6 & 7.87 & 7 & 5 & 7 & 1.31 \\
\hline Hydrocarbone & - & - & - & - & 3 & 0.29 \\
\hline Other & - & - & - & - & 1 & 0.07 \\
\hline Total & 36 & 90.44 & 38 & 92.72 & 43 & 96.49 \\
\hline
\end{tabular}

Symbol - : not detected 
Table 4. Determination of minimum inhibitory concentration (MIC) of different parts of $P$. platychlaena Boiss essential oils against pathogenic bacteria.

\begin{tabular}{|c|c|c|c|c|c|}
\hline \multirow[b]{2}{*}{ Sample } & \multicolumn{5}{|c|}{ MIC (mg/ml) } \\
\hline & Plant parts & $\begin{array}{c}\text { S. aureus ATCC } \\
6538 \mathrm{P}\end{array}$ & S.aureus & $\begin{array}{c}\text { P. aeruginosa ATCC } \\
9027\end{array}$ & P. aeruginosa \\
\hline \multirow[t]{3}{*}{ Essential oil } & Leaves & $2.54 \pm 0.32$ & $3.14 \pm 0.02$ & $1.16 \pm 0.08^{*}$ & $5.0 \pm 0.0 *$ \\
\hline & Stem(front) & $3.08 \pm 0.04 *$ & $3.18 \pm 0.03$ & $5.3 \pm 0.33 *$ & $8.5 \pm 0.76 *$ \\
\hline & Flowers & $0.86 \pm 0.13 *$ & $3.0 \pm 0.57$ & $1.43 \pm 0.06$ & $7.66 \pm 0.66$ \\
\hline Ciprofloxacin & & $1 \pm 0.28$ & $1.66 \pm 0.33$ & $1 \pm 0.28$ & $2.33 \pm 0.33$ \\
\hline
\end{tabular}

Values are mean \pm SD, Symbol * : it mean significantly with data caring the same symbol among different essentials against the same pathogen.

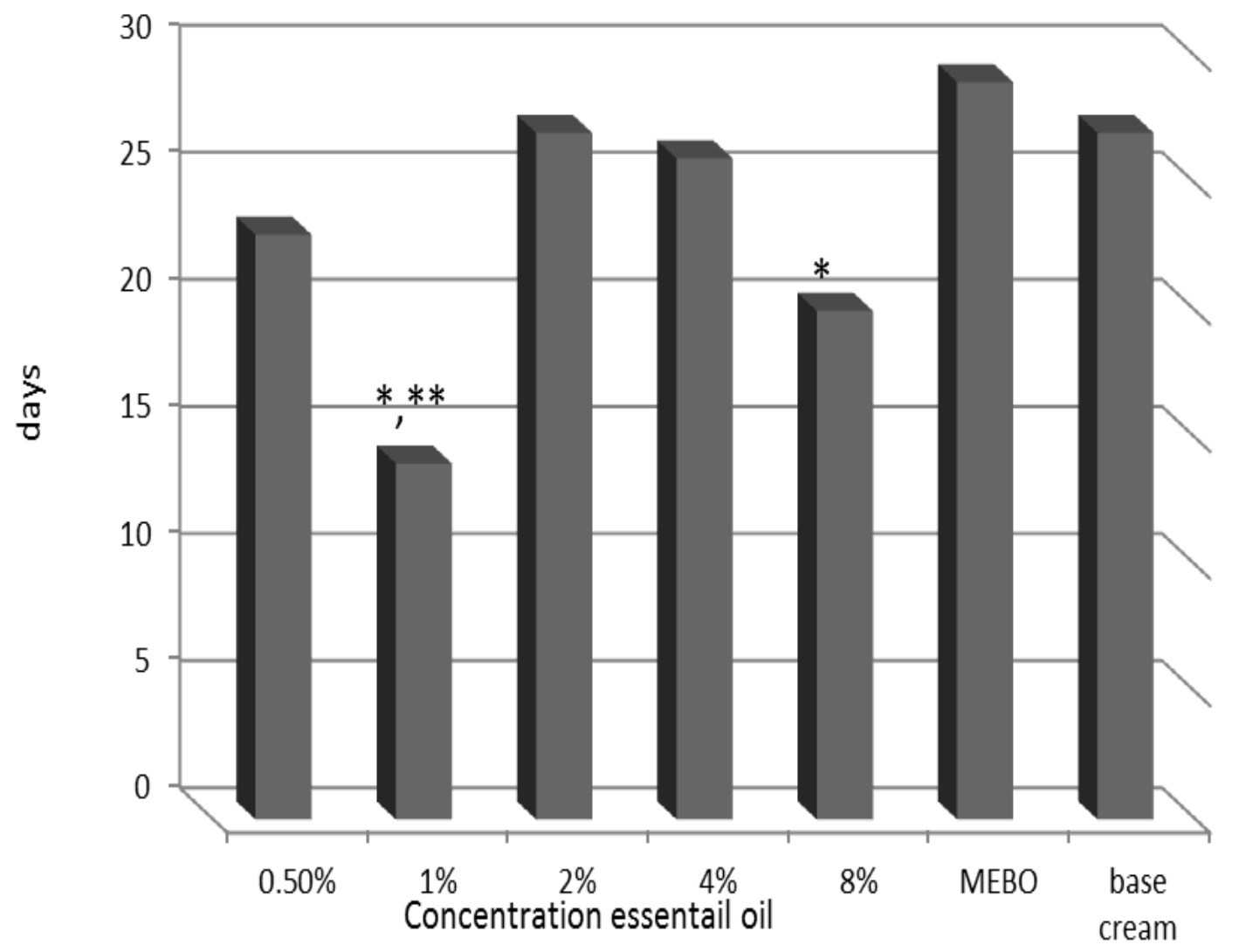

Figure 1. Time of wound healing of treated rats in different groups

* significant difference between the treated group with control groups (base cream

* *significant difference between treated groups with control groups ( MEBO) 

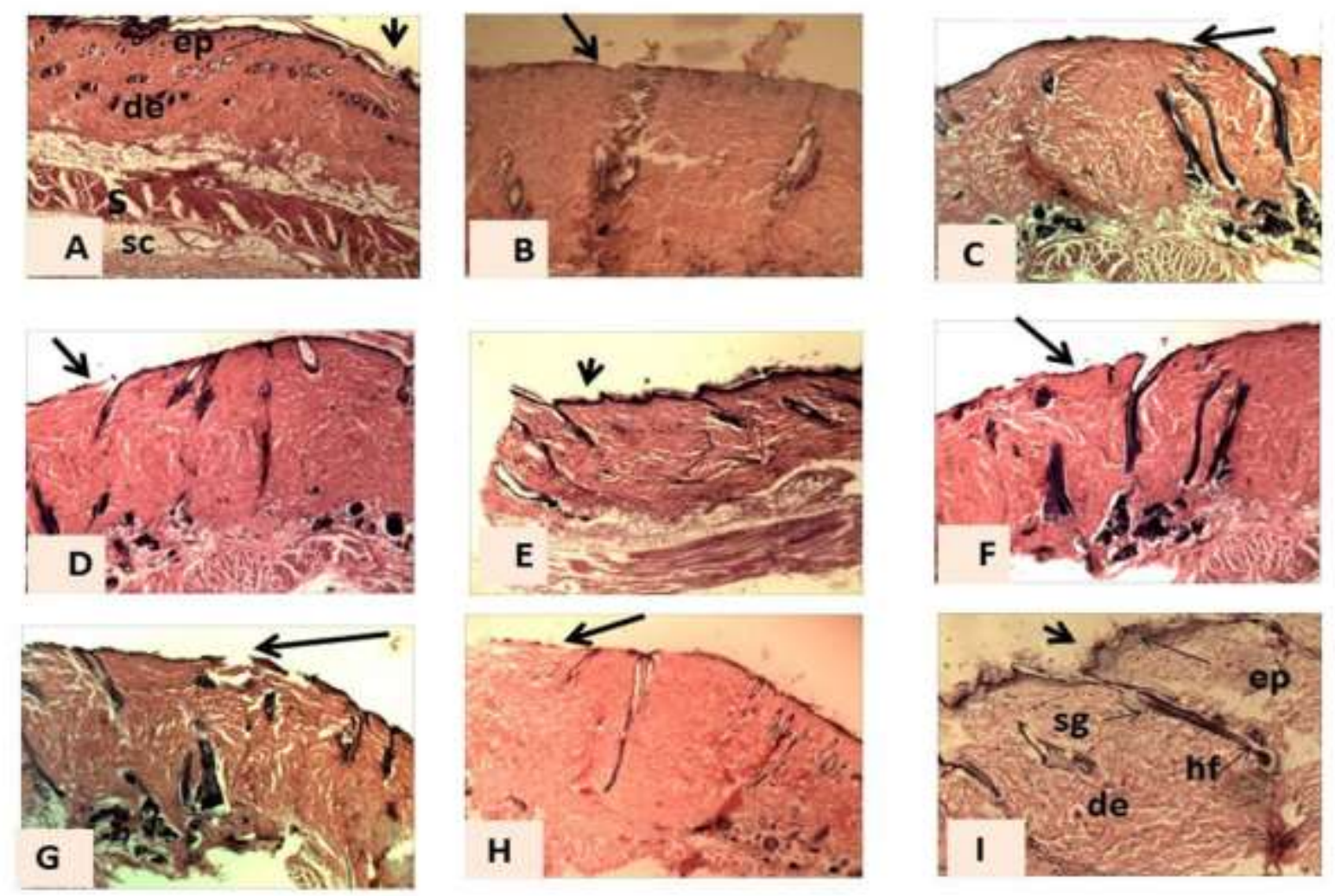

Figure2. Histological section from burned skin of rats obtained from $15^{\text {th }}$ day excision wound ( $x 40$ magnification except (I) was x100). (A) Normal control group (untreated group),

(B)negative control (base cream), (C) positive control group(MEBO), (D), (E),(F), (G) and (H)) groups of base cream containing $0.5 \%, 1 \%, 2 \%, 4 \%$ and $8 \%$ essential oil flower $P$.

platychlaena Boiss., respectively, (I) base cream containing $1 \%$ essential oil after treatment, ep: epiderm, de: derm, s: skin muscle, sc: subcutaneous connective tissue, sg: sebaceous gland, hf: hair follicle, indication of Bold arrow marks $(\downarrow)$ : incomplete epiderm, indication of head arrow marks $\left({ }^{\downarrow}\right)$ : complete epiderm.

\section{Conclusion}

These results showed that different parts of $P$. platychlaena Boiss., essential oils containing a large amount of (E)- $\beta$-Ocimene, Bornyl acetate, $\gamma$-Terpinene, p-Cymene, $\alpha$-Pinene, Sylvestrene, $\delta$-Cadinene, Myrcene and Terpinolene, which have important roles in the antibacterial activities against known pathogenic bacteria, as well as, some chemical compounds such as Sylvestrene, $\alpha$-Pinene oxide, (Z)-Epoxy-ocimene, Borneol, epiLongipinanol, Germacrene D-4-ol, epi- $\alpha$ Cadinol, 3-Thujanol acetate and Acorenone were found in $P$. platychlaena Boiss but not detected in any other Prangos species. Moreover, during this study it was found that the flower essentail oils of $P$. platychlaena Boiss have important and significant roles in the healing of rats wound.

Acknowledgments
The authers thank Dr. Abdullah shukur from the Biology Department, College of Education, University of Salahadden, for helping in the identification of plant species.

Conflicts of Interest

Authors declare no conflict of interest

\section{REFERENCES}

1.Abdel Hamid, A.A.M. and M.F.M. Soliman.2015. Effect of topical aloe vera on the process of healing of full-thickness skin burn: a histological and immunohistochemical study. Journal of Histology and Histopathology. 2(1): 19.

2.Aastan, D., P. Salehi, and H. Maroofi. 2016. Chemical composition, antioxidant, and antimicrobial activities on Laserpitium carduchorum Hedge \& Lamond essential oil and extracts during various growing stages. Chemistry and Biodiversity. 13(10): 13971403 
3.Altameme, H.J.M. and I.A. Ibraheam.2019. Rapd and Issr analysis of the genetic relationship among some species in Rutaceae ans Apiceae in Iraq. Iraqi Journal of Agricultural Sciences. 50(2): 608- 616

4.Al-mohammedi, A.N., A. F.Al-mehemdi, and O. H.Al-mehemdi. 2016. Some physical properties of essential oil of baraka seed Nigella sativa $L$ impacted by rat guano Otonycteris hemprichii camd and sea weed extract. The Iraqi Journal of Agricultural Sciences. 47(4): 1124-1131

5..Ahmed, J., A. Guvenc, N. Kucukboyaci, A. Baldemir and M. Coskun.2011. Total phenolic contents and antioxidant activities of Prangos Lindl. (Umbelliferae) species growing in Konya province (Turkey). Turkish Journal of Biology. 35: 353-360

6.Akhlaghi, H., M. Nekoei z, M. Mohammadhosseini and A. Motavaliza dehkakhky. 2012. Chemical composition of the volatile oils from the flowers, stems and leaves ofPrangos latilobaKorov. Using the head space solid phase microextraction method prior to analysis by gas chromatography-mass spectrometry. Journal of Essential Oil Bearing Plants. 15(2): 328-335

7.Bacha, K., Y. Tariku, F. Gebreyesus, S. Zerihun, A. Mohammed, N. Weiland-Brauer, R. A. Schmitz and M. Mulat.2016. Antimicrobial and anti-Quorum sensing activities of selected medicinal plants of Ethiopia: Implication for development of potent antimicrobial agents. BMC Microbiology. 16(1): 1-9

8.Bardaa, S., D. Moalla, S. Ben Khedir, T. Rebai and Z. Sahnoun.2016. The evaluation of the healing proprieties of pumpkin and linseed oils on deep second-degree burns in rats. Pharmaceutical Biology. 54(4): 581-587

9.Danielli, L. J., T. J. T. de Souza, A. J. Maciel, M. F. Ferrao, A. M. Fuentefria and M. A. Apel.2019. Influence of monoterpenes in biological activities of Nectandra megapotamica (Spreng.) Mez essential Oils. Biomolecules. 9(3): 1-12

10..Faraone, N., N.K. Hillier, and G.C. Cutler.2015. Plant essential oils synergize and antagonize toxicity of different conventional insecticides against Myzus persicae
(Hemiptera: Aphididae). PLOS One. 10(5): 112.

11..Ghazanfar, S.A. and J.R. Edmondson.2013. Flora of Iraq. National Herbarium of Iraq of the Ministry of Agriculture, Baghdad. 5(2): 109-220

12.Ginovyan, M., M. Petrosyan, and A. Trchounian.2017. Antimicrobial activity of some plant materials used in Armenian traditional medicine. BMC Complementary and Alternative Medicine. 17(1): 1-9

13. Glisic, S., S. Milojevic, S. Dimitrijevic, A. Orlovic and D. Skala. 2007. Antimicrobial activity of the essential oil and different fractions of Juniperus communis L. and a comparison with some commercial antibiotics. Journal of the Serbian Chemical Society. 72(4): 311-320

14.Gurlek Kisacik, O., U. Gunes, M. V. Yaprakci and K. Altunbas. 2018. Effectiveness of bitter melon extract in the treatment of ischemic wounds in rats. Turkish Journal of Biology. 42(6): 506-516

15.Guerra-Boone, L., R. Álvarez-Román, R. Salazar-Aranda, Anabel Torres-Cirioa, V. M. Rivas-Galindo, N. W. d. Torres, G. M. G. González and L. A. Pérez-Lópeza.2013. Chemical compositions and antimicrobial and antioxidant activities of the essential oils from Magnolia grandiflora, Chrysactinia mexicana, and Schinus molle Found in Northeast Mexico. Natural Product Communications. 8(1): 135139

16. Ibrahim, R.N., M.S. Alsalmani, and T.H. Zedan.2019. Study the antibacterial activity of Aqueous extraction of onion (Allium cepa L) against Staphylococcus aureus isolated from otitis media. Iraqi Journal of Agricultural Sciences. 50(4): 1186- 1192

17.Kummer, R., C. F. Estevão-Silva, R. L. Bastos, R. Grespan, F. M. d. S. Silva-Comar, R. A. Spironello, B. A. Rocha, E. L. Silva, C. A. Bersani-Amado and R. K. N. Cuman.2015. Effect of p-cymene on chemotaxis, phagocytosis and leukocyte behaviors. International Journal of Applied Research in Natural Products. 8(2): 20-27

18.Mahmood, A., A. K. Tiwari, K. Şahin, Ö. KuÇuk and S. Ali. 2016. Triterpenoid saponinrich fraction of Centella asiatica decreases IL$1 \beta$ andNF- $\kappa \mathrm{B}$, and augments tissue 
regeneration and excision wound repair. Turkish Journal of Biology.40: 399-409

19.Nasiri, E., S. J. Hosseinimehr, J. Akbari, M. Azadbakht and S. Azizi.2017. The effects of Punica granatum flower extract on skin injuries induced by burn in rats. 2017: Advances in Pharmacological Sciences. 1-8 20.Orhan, İ. E., B. Özcelik, M. Kartal and Y. Kan.2012. Antimicrobial and antiviral effects of essential oils from selected Umbelliferae and Labiatae plants and individual essential oil components. Turkish Journal of Biology. 36: 239-246

21.Özek, G., E. Bedir, N. Tabanca, A. Ali, I. A. Khan, A. Duran, K. H. C. Başer and T. Özek .2018. Isolation of eudesmane type sesquiterpene ketone from Prangos heyniae H.Duman \& M.F.Watson essential oil and mosquitocidal activity of the essential oils. Open Chemistry. 2018. 16(1): 453-467

22.Silva, A. C. R. d., P. M. Lopes, M. M. B. d. Azevedo, D. C. M. Costa, C. S. Alviano and D. S. Alviano .2012. Biological activities of aPinene and $\beta$-Pinene enantiomers. Molecules. 17(6): 6305-6316

23.Silva, S. M., S. Y. Abe, F. S. Murakami, G. Frensch, F. A. Marques and a. T. Nakashima.2011. Essential oils from different plant parts of Eucalyptus cinerea F. Muell. ex Benth. (Myrtaceae) as a Source of 1,8-Cineole and their bioactivities. Pharmaceuticals. 4:1535-1550

24.Sachdeva, K., P. Garg, M. Singhal and B. Srivastava.2011. Wound healing potential of extract of Jatropha curcas L. (Stem bark) in rats. Pharmacognosy Journal. 3(25): 67-72 